\title{
INVESTIGATING COMMUNITY RESILIENCE AGAINST VIOLENT EXTREMISM THROUGH LIVED EXPERIENCES OF COMMUNITY MEMBERS IN SWAT-PAKISTAN
}

\author{
Muhammad Idris $^{1 *}$, Said Saeed ${ }^{2}$ \\ ${ }^{1 *}$ Assistant Professor, Department of Education, Abdul Wali Khan University, Mardan, Pakistan; ${ }^{2}$ Principal, Elementary \\ \& Secondary Education, Khyber Pakhtunkhwa, Pakistan. \\ Email: "midrees@awkum.edu.pk
}

Article History: Received on $12^{\text {th }}$ April 2021, Revised on $30^{\text {th }}$ April 2021, Published on $7^{\text {th }}$ May 2021

\begin{abstract}
Purpose of the Research: The paper focuses to investigate CR (community resilience) counter to extremism through the lived experiences of community members.

Methodology: To gather appropriate data from the partakers, the qualitative research design was applied. To analyze the gathered Clarke and Braun (2014) thematic analysis approach was used.

Results: The results of this research work were construed and the ways forward were fitted out given that. the project team is in the process of initiating a report that focuses on strengthening community capacity, which is the main objective of this paper. The edition will make a positive contribution to all interested and humane people, mostly to the less fortunate.

Application of the research: Moreover, it can be said that this project will have an impact on future research in the field of community empowerment. This work will also highlight the important opportunity for historical research on community resilience to combat violent extremism.
\end{abstract}

Novelty/Originality of the research: Past research has sufficiently investigated similar topics. However, none of the past research approached the topic through the lived experience of the community members. Thus, this research (by studying the problem through the lived experience of the community members) is unique.

Keywords: Ferocious Radicalism, Communal Pliability, Public Enablement, Community Membership' Starring Role, Community Character.

\section{INTRODUCTION}

Over the past twenty years, political, religious, and ideological savagery and barbarism have spread around the world. This led to a nearly tenfold increase in the death toll from the 9/11 extremism. Pakistan and Nigeria, which have the highest number, responsible for death are the fanatic factions who demonstrate a high standard of freedom. Extremism is opposition to fundamental principles, which comprise egalitarianism, the rule of law, human rights, reciprocal reverence, and big-heartedness for diverse dogmas (Muzamil, Tschakert, Boruff, \& Shahbaz, 2021).

An organization is a cluster of individuals and crowds who have similar safeties or have a geographical area. Local resuscitation (CR) is a sign of stopping negative violence from those who have been sacrificed to sustainable change. Communal spirit acts in the fight against all forms of extremism and discrimination. The government's commitment to respect for anthropological civil liberties wins community support against all forms of activism. Ahmed and Zahoor, (2020) presented Hirschi's (1969) theory that strong family, community, and social relationships play a central role in overcoming strong extremism. Researchers propose collective efficiency, which is the unification of community solidarity with plans to take stronger action against larger communities - as a major shadow of the impact of environmental terrorism (Akram, Nasar, \& Rehman, 2021). Alam, (2021) introduces a community resilience system that includes financial development, information and communication, modern infrastructure, and community resilience. These principles are the theoretical framework of this research project.

Extremism poses a threat to the entire world. The main source of violent terrorism in society. The number of people who have died as a result of violent violence is similar to other forms of violence (Bhattacharya, 2020). Being a member of the community can play the best role in preventing violence with the complete involvement of individuals to produce the essence of proprietorship of this challenge and solve it. The best strategies to prevent violent conflict are to strengthen interpersonal relationships, streamline inter-agency programs, and resolve inter-city and financial crises that promote interdependence, perpetuate inequality and inequality and increase community engagement (Bilal, 2021) Davies, Doering, and Neudecker (2021) mentioned (Sampson, Raudenbush, \& Earls, 1997) have developed a theory of improved performance - a community-based approach mixed with illness to enter and communities- an important protection impact concerning regional issues. Successful coordination of conflict and traumatic situations is called resilience (Fair, Littman, Malhotra, \& Shapiro, 2018). A community is an environment where people live together. Social norms such as perceptions of similarity and proximity, common features such as religion, ethnicity, and nationality are given priority in anthropology (Hussain, Mushtaq, \& Hussain, 2021). Community resilience combines the ability to integrate into a better way of working and re-functioning in a community before bullying or disaster (Kapur, 2021). 
It takes time before the public engages in the detection of VE, on individuals and organizations involved in these heinous acts, along with showing support agencies and their organizations. Many strategies can be used to eliminate VE, such as tackling extremist mobility issues, raising awareness, sharing information and promoting a peaceful cultural environment, focusing on table discussions and improving patient behavior, and using educational and media positions in this regard. We can deal with people's complaints effectively. These strategies are very important, such as tackling racism and unequal employment opportunities and organizing social programs for vulnerable youth to overcome social, personal, political, religious, extremist attitudes. This paper aims to ascertain empowering community members and strengthening community resilience to life-threatening activities, building from top to bottom and from bottom to top. Community members and communities can eliminate radicalism from the minds of the younger generation through awareness and education and the enjoyment of life. The study is important because it focuses on the community's resistance to terrorism. This further clarifies the situation on how to define strategies to achieve sustainable development goals, empower community members to fight terrorism, and strengthen public confidence in the face of this devastating threat for people (Kundnani, \& Hayes, 2018).

The human being is selfish. He loves wealth. He kills his brother for small and temporary things like land, money, and political prestige. Members of the international community are engaged in the game of killing innocent people. They have set up large arms manufacturers and are seeking financial support for the sale, seeking different parts of the world to sell their weapons and obtain financial support (Majeed, 2021).

Individuals' education is vital to get mindful about the danger of ferocious brutality and fortify the fight against intimidation and prevent individuals' involvement from unlawful factions (Malik, He, \& Rafay, 2019). Resistance factors were established to place resistance communities under harsh conditions (Mehfooz, 2021; Ma, Guo, Deng, and $\underline{\mathrm{Xu}},(2021)$. Community discouragement can isolate factors that lead to conflict for communities, such as violence (Onwudiwe, \& Mendie 2021). Extremists exploit the young generation and recruit them in their groups for accomplishing their nefarious design. Those who want to be spectators must make society more resilient by falling into the cold and maintaining a protective experience (Pervez, 2020).

Research has found that due to the extreme behaviors of others, people change from a normal state to a life-threatening condition (Ramakrishna, 2021). Terrorism and racism among rulers, as well as fear of security, investigation, and ethnic/religious meanings, are key elements of intense violence (Rehman, Abbas, Khan, Mustafa, Fayyaz, Hanif, \& Saeed, 2021).

\section{Significance}

This paper is significant to fetch modifications in prevailing procedures to promote communal buoyancy against brutality. It is too important for decision-makers to understand the role that education and community members, play in the fight against terrorism and to review their policies to raise awareness among young people about this threat, to ensure organizations and communities entirely on intentional terrorism and cancer treatment. It can also be important for educators, analysts, leaders, fathers, and mothers; community members, teachers, and students to receive guidance from CRVE. The study may suggest an appropriate way for national curriculum creators to combine anti-terrorism issues in courses that make the program more effective, engaging, and attractive to members of the community, followers, and followers of community members. Ultimately, educational organizations can produce better members of the community who dedicate their energies to human development.

Research does not impede the respect and protection of the sovereignty, rights, and integrity of participants. They are informed about the use of the information they have obtained. Reverence, privacy, and translucence are maintained. Dishonesty, cheating, injury, law enforcement, uncleanness, professional integrity, health, quality of review, origin, and other ethical factors. Cultural integrity is respected. A widely accepted language is used.

\section{Research problem}

The paper aims to examine the state of society in the face of extremism through the experiences of community members in Swat; to know the root causes, strategies, social interactions, and community status in the fight against extremism?

\section{Research questions}

$\mathbf{R Q}_{1}$ : What are real sources of ferocious vehemence in communal associates?

$\mathbf{R Q}_{2}$ : What tactics can be executed authorizing communal associates and fortify the CR with improved counter-terrorism strategies and encourage them to develop effective counter-terrorism strategies?

$\mathbf{R Q}_{3}$ : What are the social interactions (social integration and inheritance) between communities and institutions to increase social cohesion? and

$\mathbf{R Q}_{4}$ : How do community members and communities play a role in thwarting ferocious vehemence? 


\section{LITERATURE STUDIES}

Norris and Alegría (2008) present a system of community resilience that includes financial growth, information and communication, common tools, and community opportunities. These essentials are very effective in easing anxiety. Sharing wealth is the ability of community members to make a profit through social networking or public forums. Sharing wealth involves the brainchild of a community organization based on beliefs and proximity to the community; the ability to connect with the community depends on public participation in dealing with neighbors and the participation of organizations. In this regard, the social sustainability of a community within a community, as well as its relationships with organizations, are critical to the strength of a community. Similarly, community experience demonstrates effective collaboration to achieve goals. Community competence includes shared impact - the success of strategic partnerships and empowerment (Norris \& Alegría, 2008).

Community resilience depends on strong community groups among members of the community as well as between groups and community members (Chandra, Williams, Plow, Stayton, Wells, Horta, \& Tang, 2013). Association, civil society, social media, property sharing, vigilance, community mobilization, private engagement, and consolidation of organizations are vital for constructing communal power (Hong, Bonczak, Gupta, \& Kontokosta, 2021). Communal interconnection (in communities) and social cohesion (between associations with different ethnic backgrounds but the same meaning) and social cohesion (between communities and organizations) reduce the risk associated with violence.

It has been suggested that the effect of cooperation is the cooperation of individuals in coordinating a strong response to terrorism, which is a major factor in creating a shadow over the terrorism surrounding it (Richards, 2020). Participating with donors to promote honest trust and cooperation can eliminate terrorism. There is a significant correlation between the experience of discrimination and acts of violence (Burt, Simons, \& Gibbons, 2012). The main causes of violent extremism are negative emotions such as despair, hostility, and inequality between individuals, communities, the abandonment of conservative attitudes, and the weakening of society and governing bodies. Many minority groups are at risk of domestic violence due to financial differences (Piazza, 2011).

According to the survey, Muslims face severe political turmoil in Europe and the United States because they are different from the indigenous people. Selfishness is an area of concern that foreign groups resent, leading to the behavior of some extremist minorities, which in turn can lead to an increase in discrimination within the organization, which in turn can exacerbate it to external group complaints (Victoroff, Adelman, \& Matthews, 2012). Muslims have reacted angrily to anti-extremism programs in three U.S. cities because only Muslims have been violated without violating their constitutional rights (Romaniuk, 2015; Weine, Cohen, \& Brannegan, 2015). The fight against extremism has become less conscious and has limited resources for other social issues, such as gang violence (Schanzer, Kurzman, Toliver, \& Miller, 2016).

In this regard, these fears can be addressed by building genuine partnerships between communities and governing bodies to strengthen stronger communities. Community awareness prepares people for all kinds of disasters, ( $\underline{\text { Hong, Bonczak, }}$ Gupta, \& Kontokosta, 2021), societal connections are imperative for CR to catastrophic disasters. Determination in race, ethnicity, and spirituality is essential for a society's resilience to serious illness and conflict, acting as a protective shield, reducing the risk of coercion (Svennevig, Jerome, \& Elwick, 2021; Hodge, Zidan, \& Husain, 2015). Fear of Islamic ideology incites extremism and bigotry (Wahab, 2021). Their shortcomings are the lack of education, the negligence of members of the community, and the isolation of a society that encourages terrorism. The purpose of the study now is to fill these gaps.

\section{METHOD AND MATERIAL}

Qualitative methodology was used for this study. The purpose of this approach is to get an unfathomable contextual connotation of violent extremism and its impact on society in a natural scenario. Phenomenology is one of the five approaches highlighted by Creswell and Poth (2016) to get a thorough thoughtfulness of violent extremism through the lens of the participants. A convenient sampling procedure was adopted to collect data from participants to present comprehensive descriptions and exactly reveal their point of view for exploring root causes, strategies, social linking, and community membership role against violent extremism in Swat.

\section{Participants}

The purpose of the investigator is not findings generalization to the population but a bottomless and profound thoughtfulness of the topic through familiarities and practices of participants. The number of participants was 04 female community members and 04 male community members [04 community members (female) +04 community members $($ male $)=08]$ of District Swat who had experienced violent extremism in the valley of Swat were chosen.

\section{Data Collection tools}

In-depth interviews with participants were the research tools. We were keenly engaged with the participants in the data collection procedure. In this way, diverse facets were gained in discovering the practices and experiences of community members and community members in Swat. 


\section{Interview}

Appropriate research methods are very useful for academic research. The cost of looking for these methods is very low and the results can be very focused and useful for many areas of study. On the other hand, the benefits and differentiated nature of qualitative research methods vary from subject to subject and from training to training (Milena, Dainora, \& Alin, 2008).

A phenomenological study is conducted through in-depth interviews which is the most important strategy for data gathering (Ting, Yong, Yin, \& Mi, 2016). According to Tavakol, Dennick, and Tavakol (2012), an in-depth interview is essential for understanding the true spirit of the research problem and gaining new and novel themes from the lived experiences of the informants. We applied in-depth interview sessions with the participants. The interview queries was framed based on RQs. The interview sessions were continued until the data gets saturated. The participants' experiences were noted down for records to get an understanding of the phenomenon.

\section{Validity and Analysis}

The research tool (interview protocol) was validated and corrections were made as directed by the experts. Interpretative Phenomenological Analysis (IPA) was applied for the analysis of the gathered data. Interpretive phenomenological analysis (IPA) practice, the narrative was also employed within the IPA practice to collect the partakers' community membership stories (Hearn, Finlay, \& Sheffield, 2021). Steeves (1994) mentioned the narrative as demonstrating the "world in motion" (p. 23), thus, the first interview question was structured in narrative form, questioning for the partakers' story of community members to deliver a more vibrant value to the interview. The findings commence with these retorts.

\section{RESULTS AND DISCUSSION}

Seventeen across-the-board themes emerged from the interviews: (1) achievement of political, religious, and ideological goals; (2) challenging governmental functioning; (3) terrorism knows no rules; (4) creating public fear; (5) cultural constraints, (6) publicity fear and anxiety, (7) rational, psychological and cultural terrorism, (8) religious extremism, (9) inspirational speeches for recruitment, (10) factor achieving goals, (11) torture and slaughtering, (12) Glass ceiling, (13) Modesty, (14) root causes (15) combating strategies, (16) social linking, (17) community membership role. The most relevant to this study were the last four root causes, combating strategies, social linking, and community role.

\section{Stories of Community Members}

While we asked questions from community members and community members to state and express in detail the story of their experiences during terrorism of the terrorists and then during the operation of security forces, the responses and angry replies displayed life-threatening discrepancy among the participants. Some community members discussed their adept and dedicated efforts, some debated more heart-piercing stories, and others contended their community [The Valley of Swat] suffered a lot from the hands of violent extremists in the garb of clergymen. Two of the partakers, Sardar and Yousaf, told that violent extremism has completely devastated our education system as they have attacked and usurped the educational institutions by force and demolished most of the school and college buildings so. Sardar narrated his story of facing terrorism first as "dearth of political sagacity strengthen the presence of violent extremists in the valley, Oh, I wish I would rather be a pagan to see the leaders of dogma, puppets in the hands of terrorists, making slogans for a so-called Shariah- the arch-rivals of the real Mullahs- the best social reformers-the leading lights of social order."

He then continued to express the devastating condition of his community membership, starting with the explosion, bombing, assassination of prominent figures and opponents and then with migration as IDPs- Internally Displaced persons starting with being Proctor of the Students' Proctorial Board [SPB], as well as other leading roles like Head of Debate Society, Stage Secretary at Bazm e Adab program at secondary school level. He restated that he sensed pleased and respected that followers regarded him and that he incessantly makes every effort to mark a change as a leading light and as an individual.
"The story of my membership has been going on since the beginning of my life at the institutional level. When I worked as a different member at different levels, I was very satisfied with being in the community seats, either formally or voluntarily, I was very happy to have the opportunity to do so, some people found me to look after good deeds. I feel like I was going to a victim level at the time, and I feel like I want to make a difference, whatever it is."

Yousaf explained that their local members "have grown and grown after 27 years." He immediately took on his skin color and gender and that he grew up in the city of Peshawar in Ninety Years. This laid the foundation for the development of its local members. The integration of inter-ethnic communities has given the power to speak to those who have not yet been left out. He did not identify himself as a leader because he saw Fatima Jinnah, M.A. Jinnah, Benazir Bhutto, and Razia Sultana as members of the community. He has come a long way in his life, as he recalls his enlightenment, understanding, and actions which he understood saying "almost at all times he is a leader, I have never seen." He describes himself as a "compromiser" and a "bee-like worker," rather than a leader. 
"So I have a strong foundation of leadership since my student. I will always be active like a bee in the activities of my members to enjoy others. If something needs to be completed, I can figure out what needs to be completed. I used to lead a group of students, and I did all sorts of work in student groups. I was put in the seats of community members even though I never knew I was a leader".

His domestic life, especially his father-in-law high school, influenced the style of membership of his community. He announced that his father had made many sacrifices to have a better life. Yousaf, as a young man, tried to agree to take it and would meet his father's choice. "I think his words, every time I take care of it, I see this work so you don't take it. That's why you keep going to school, that's why you go to college; so that, don't take it for granted. "He got into this in his leadership. He, like his father, was smart enough to" discuss the situation so that you get what you want without neglecting to leave who you are ".

Sadia begins her story by describing the members of the group as "full details of you as a complete person." He then went on to express his belief and belief that community members are more than just one person's experience, know-how, and day-to-day activities. He points out that in recent days he has been successful in a unique development platform in the workplace where the researcher started with asking questions about his youth. He described his unique experience as a "bright spot" to see how he felt about his idea of becoming a member of the community. He was very careful about how management and leadership were something more important than just the curriculum. He went on to say that the history of the world has been enriched in every age by the birth of great city members who were a symbol of loyalty [Like my Father - Deputy Commissioner of the time- martyred in a burst of tears in his eyes]. He went on to say that from the dawn of civilization until now, these members of society have been born in all countries and all human races. But it is unfortunate about the fate that few of such great souls are properly accepted, not highly respected, in their lives and even by their followers - followers who have suffered and been martyred. Their destiny ranged from death to judgment. He also brought information [Thus Christ was crucified; Socrates had to swallow the poison; Hazrat Muhammad (SAW) emigrated for his life; Galileo was cut off as an innovator; Quaid e Azam was condemned and Mahatma Gandhi fired a bucket for the shooting and the assassination of Benazir]. He went on to say that dignity and acceptance will not go hand in hand, while these members of the society are alive, misunderstood, misunderstood, abused, cursed, and even persecuted. But when they were not, when the time came to discard the madness of misunderstanding, determination, selfishness, and conflicting passions, then the great leader accepted his true position and shone in all his glory. But [crying]. No tears, no tears, no praise can come to him. Then it goes beyond all this.

\begin{abstract}
"Of course we do not disclose any particular area of whether a person is a strong and resilient hero or a professional leader or a natural leader. If you try to talk about members of the community illegally, just about my academic credentials, compliments, special disclosures, and work experience, you are misleading something True plenty about human totality".
\end{abstract}

Shehzad begins his story with his professional and thorough consent but focuses on being in a specialized centre, not on any important position he wants to achieve. He informed each other that his dream of doing his job at this high school was so strong that he took an evening job just to get a position there. It is for this reason he has become brilliant in finding more work so it will be day and night and last forever. He caught and bought more writing than, a few columns, all including one post watch.

He explained [Attended a training workshop organized to assist women to become caregivers with HODs at the University. It was for this training session that he was able to engage in many facets of the university and have had regular success, some of which he still has. The various areas he held first in his career made it easier for him to advance as he managed the skills he developed during that time of his career].

Shehbaz was quick to define himself as the inventor of "forward power" rather than "born leader." Explains his preferences for being in the constitution or control as a leader. However, it shows union members to demand "such selfcontrol and self-control which is not normal." Shehbaz went on to describe the training necessary to be an honest and effective leader. The discipline is to obey our leaders and our followers. The whole world is disciplined. Violation of one of its minimum rules will lead to disaster. The public also stands for training on the global system. He went on to say that we should obey each other, obey the laws of nature, and obey the laws of God. It is important in all areas of life [at home, in college, at work, on the playground, and even in senior positions]. He went on to say that discipline [effective among community members] is the key to success in modern management. It is a virtue. They are important members of the community as they are thoughtful, visionary, and visionary people; seekers of truth and justice; fighters for truth on falsehood, knowledge for superstition, and light on ignorance; dreamers of perfection and the greatest human happiness; a special group that lives for humanity as a whole and is fighting for their lives as a whole to enjoy the greatest human being in society; they are in line with their mission, their dream of pleasing all men. As a result, they are farther away from their peers - this makes some envious of them and when they start promoting their good qualities, few support them and many oppose them. They are abused and ridiculed and when they use their influence, they begin to show unfounded prejudices and beliefs. They are then violently attacked and often mistreated. But these unique inventions do not break down and become bold and active. He sighed and said [if your head is thrown, then it stands above the rest]. 
"If you want to be a good leader, you must always jump to zero. So purify your skills to be polite and take responsibility for yourself and get a degree that is highly susceptible to exposure, and find out that you are making mistakes and mistakes. And, accordingly, I'm considering what it takes for a person who is motivated to organize all of this and I don't think what was born. But from the point of view of purification and being in order to move forward as long as you want yourself... from the perspective of continuing to be as resilient as you possibly can, this is why I say I don't think it really is essentially an elegant machine. If you are a unique creature, you can do anything. Members of the community were born some people believed. Members of civil society are formed by things that I believe in. If you are born a leader or a leader, you must face opposition and opposition if you want to apply your best practices to the happiness of others and the advancement of the organization".

\section{Community Membership Tactics}

There are many qualities that are the cornerstone of any leader. These include responsiveness, improvement, and collaboration, creativity, innovation, appreciation, and communication. These attitudes are part of the activities of the members of the organization outlined below.

Sidra mentions the status of a member of his community based on conservation, collaboration, appreciation, engagement in activities, and the audience listening.

"There are many attributes and a cloud carrying each leader. Programs include responsiveness, photography, self-planning, creativity, publication, appreciation, appreciation, and communication. These qualities are among the most important members of a well-developed and well-watered community.

Sidra mentions the greatness of a member of his community in terms of keeping up, working together, showing appreciation, engaging in activities, and listening to the audience. Being a member of a community is about acknowledging that it must be maintained, that it is important to connect with people and to promote human dignity, it is different from cooperation and collaboration, and it is not about working together because I do not feel that I have understood or know how to make a decision, but it is the belief that as you connect with people and develop more people, they feel more part of the group. My job doesn't do all the work; my job is to engage people to feel a better understanding of the project. My job is to be a leader of good character, to be a visionary, to be dependable and dependable, is to plan the hard work we do. It is a proper and appropriate treatment for people who do not speak and become a speaker. So my role is to confuse people who will respond to protect the community. I have noticed that this is my style, he is to be the supervisor and supervisor of this large group of people and to keep the group safe because no one can do that."

Sardar argues with former members of his organization about its members 'values, values, vision, way of life, and beliefs.

In my opinion, the real belief is about trying to tell people, ok, let's explain the issue. Let us explain the problem. Let's find out what we are struggling to do. Let's fix the borders, now let's unite, let's work together, what do you think? What is your opinion? 'So, it is best to... strive to be a leader, planner, architect, executor, assistant, consultant, founder, decision-maker to solve the session.

Sardar went on to return to his members using a box of tools. "In the toolbox, you have to state how you want to lead in that specific time or situation or context." He further explained that at the time of a company, sometimes a mallet is the best tool for operation and at this time, one needs a machine. In his administration, he discovered that unwanted things require a variety of strategies.

The facial expressions of the kindness of the members of the group that Yousaf emphasizes focus on people.

How do you impact change? How do you motivate people to plan what needs to be planned? How do you develop organizations to move forward? And so I, too, are the key to being unique in everything, to the management experience of... grace followers. You have to focus on people. When I got caught in hot water, I didn't finish well because that's why I was so full of work with the operating system and I failed to think about the impact and people stuck and getting them to plan change. And I remind you that it is a very difficult thing, to not bother telling him what you want to achieve and just to achieve that quickly. The result for myself is the key to balance. How do you change followers?

Shehzad expressed interest in Yousaf's work of moving quickly and understanding the value of focusing on the project.

I have committed some crimes, when I was a teenager, you see trying to move things in a hurry. This is the kind of mistake that people make quickly and you try to move things fast, it takes a long time. 
So I learned about the importance of work. It's not just about the results, but also about how you transition to that. And so I found an order about these things and activities.

Shehzadi puts her management style based on her good deeds of good character. She describes herself as always doing things, whether at work or not, she is always "connected" and always discusses matters, even with relatives. There are other qualities beyond that which she permeates in her management style. These include being assertive, responsive, setting a role model for his or her employees, and maintaining attention and well-being.

She attempts

to set a good example for all my leaders and individuals who do the same to me; to show the qualities and attitudes that I want to embody in them is a positive assumption, to be receptive, to be a balanced outcome; to develop a humorous qualification, and be a woman that people want to work with and get together when we focus and think on issues.

Sadia was asked about the style of membership of her community and she responded by describing the nature of her character. For Sadia, his character in a straight line combines with his management.

I am a well-organized, non-judgmental teacher. But, the best thing about the professional experience I have experienced is understanding that, even though those are special skills, and I have not done anything to make those who are sad and I see their true value. That, in order to lead the truth, I must stand firm in this unholy way. And obviously and evaluating and improving team activities so that even if I envision things in a neat and orderly way, and you see, I have professional colleagues here (university) and other places I have worked who are not misunderstood and it is a thought otherwise and understanding how it will fetch how the se different ideas are enlightened and enlightened in a way that will last only to think through misunderstanding will not see.

Sadia then highlighted three key elements of their membership process, which included coordination, commitment, and responsibility.

The first will be to work together. From the value of different positions in the production of quality products, and about the people who feel the promise. And the second quality that is important to me is inspiration. And, being the next competitor, not only in college but also as a mother, because I saw being a mother also being a trailblazer [front-runner] and I got three girls. Understanding the number of falls you experience with revelation without judgment. But then also responsible. So the balance between revelation; but also make people responsible. You can't just be a cheerleader on the side of walking yay, yay, yay, good career. You also have to take responsibility now that this is what we accept, we have no influence on this, what happened. So, um, style of management, I see those are the differences that tease my thinking, integration, weight, and inspiration.

Shehzad recounts how he singled out someone from the management for the reason that one is not cohesive and cohesive. This established a habit for stability and the division of its heads up to unity.

I think when I went on to head the same department, everyone recognized him. It is a very difficult job. One of them realized he was not a union worker and a co-conspirator, so the meaning was clear.

\section{Creating an Optimistic Work Environment}

Fashioning a constructive working atmosphere was vital to these females' management approaches. They sensed that since individuals devote a huge quantity of time, vitality, and dynamism at exertion, they must have a constructive atmosphere, at liberty from chinwag, futile talk, backstabbing, and backbiting.

Sidra arrays the platform for individuals to be pleased and contented at toil and adore what they function. Even without elevations, he has instituted self-esteem to be winning, and he ascribed this to the constructive working atmosphere.

I reflect the extreme pleasure I have is that just looking persons thrilled about what they see to. That's what I value for I ponder that if you're optimistic, then persons all over the place you are going to be optimistic and it's going to make for a more constructive working atmosphere.

Shehbaz reiterated these ideas and was thrilled that creating a satisfying and satisfying environment was a top priority for him.

It is important to me that the people who work for me on a daily basis, under me, are satisfied with the commitment and satisfaction of their careers and provide a workplace here because we spend a lot of time planning. Its fun, but without discussion and lack of things like that. It is important for me to have a comfortable room to work where people want to come to work before lunch time.

Shehzad strives for a better working environment and upgrades the departments to work together and provide mutual support and is pleased with the satisfactory announcement. He changed the culture of the institutions 
to something more divisive than a show of power, one that was with his predecessor by convincing them to work together.

We all have different design plans in different parts and so such is important for me. I don't expect a lot of internal gossip, confusion, fawning, browning, toadying, flattering, sycophancy, and material. In our products, they are all free to say whatever they want within the limits. They can play with me, I don't care. But, nearby, once we make a decision, I don't expect anyone to challenge him or do those things. So, this is important. Of course it is almost a feminine feature.

Yousaf strives to create a positive atmosphere and uphold an optimistic attitude, even in adversity.

You will never see me as a loser about something, even if it is really ruined... so even if the financial plan punishes all this, it looks, you understand, what it is. So, what can we do to make the best position? And the piece of this too, can be too, it is developing very well and you have to make the best of it. So I think being optimistic is very important for you as you have to look at all kinds of situations and any time can be seductive. And this is plenty of halal things, but I just chose not to focus on those. I see the name 'this and I see this is something we need to address. But I refuse to let these things dictate how I live.

\section{Dealing with difficult situations immediately}

Many members of this community have talked about the need to solve problems immediately. For some, it comes down to what one wants because there is a reason why the impact on the department when protests or snags is high.

Shehzad explained

I am a very passionate person, but I am not weak. And that is the difference. So actually I don't have much respect for people who will only care to let go of the troubles they will cause because of just discomfort rather than dealing with it. This is my personal quality. But from time to time it is easy to take care of something or make a decision which such takes a very simple approach and it is important to me that I do not do so. I would be divided and humiliated if I avoided trouble because it was so difficult.

For Shehbaz, solving problems is something she doesn't like, but she thinks it's important to deal with them directly.

I let my followers see that I will not let problems escalate either I will take care of them, the issue of staff or otherwise I see everyone fighting against the opposition but I have no one to let go of, me and his time. I will continue to take care of things and I will continue to do so.

$\mathbf{R Q}_{1}$ : What are real sources of ferocious vehemence in communal associates?

$\mathrm{R} 1$ explains ignorance and adversity are the major reasons of violence. $R 2$ states that America's involvement is the main reason for the spread of this problem. $R 3$ believes that Western art is the cause of terrorism. $R 7$ argues that injustice in society to poverty leads to terrorism. $R 8$ responds that the greed of members of the international community, especially in the West is a major cause of terrorism. He also said that this has instilled the essence of crusade among young Muslims for retaliation and others.

$R_{2}$ : What tactics can be executed authorizing communal associates and fortify the CR with improved counterterrorism strategies?

$R 1$ is of the opinion that Peaceful political dialogue and cooperation are the finest stratagems to encourage communal adherents to combat intimidation. $R 4$ shows that mutual understanding, communal involvement, and societal fairness are indispensable for suppleness. $R 6$ replies that eliminating fear of Islam by pacification actions is a good approach. $R$ 2 retorts that reformation of ideas, cessation of hostilities, and closure of preparation hubs are good stratagems. $R 3$ displays that backup a robust public is a good tactic.

$\mathrm{RQ}_{3}$ : What is the societal relationship (integration \& inheritance) of peoples with organizations to enhance communal capacity?

$R 2$ says communal cohesion, and societal interconnection is indispensable to address ferocious conflicts. $R 7$ states that public consciousness of education is crucial for pliability in society. $R 4$ states elimination of self-deprecation, positive political style, and being a strong member of society are protective to increase the bonds of friendship and affiliation with the union of vehement fanaticism. $R 5$ reported the delivery of education and financial strength are factors to strengthen the strength of the society, among others

\section{$\mathrm{RQ}_{4}$ : What is the role of communal members in thwarting vehement activism?}

$R 7$ states that the role of a local member is constructive in fetching extremists into strata of life time. $R 4$ responds community members may like nonviolent work. $R 6$ responds to human dignity, morality, and morality can be maintained. $R 3$ responds that family gatherings, commitment to a better future, and social status can be respected. R5 
said the members of the town and the community are working together to prevent fraud but also save the innocent. $R 4$ exposes that members of academic communities can bring peace; eliminate bias from any form; broadening the mind, broadening the vision, strengthening the intellect, and developing the power of a positive community. Motifs are appraised regularly.

Architectural representation of Themes.

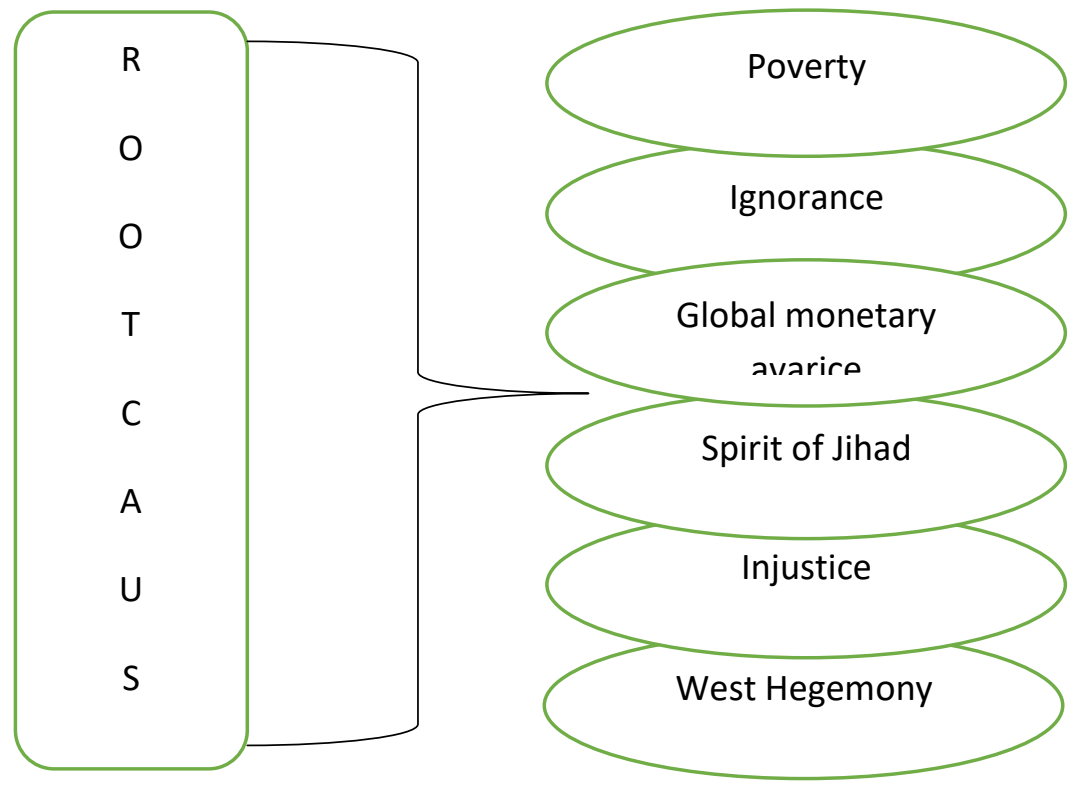

Figure 1: The emerging theme of basic reasons

\section{Source: Authors' Work}

The figure shows that the basic reasons for ferocious radicalism are extreme adversity in the area and no proper educational programs for the eradication of illiteracy and ignorance from the youth of the locality. Spirit of Jihad was inculcated in the mind of the youth with so-called ideology and they were recruited regularly and properly by the extremist groups for the fulfillment of their nefarious designs. Injustice is rampant in the area. All the fiscal authority are in the hands of Khans. They were treating the poor with brutality and injustice. An inborn hatred is existing in the poor people against the landlords of the area. It was also found that global monetary avarice to snatch each and everything of another country was another cause of the violent extremism. It was also found that nefarious designs of the West have devastated the conditions in Swat because these countries have their designs in the area.

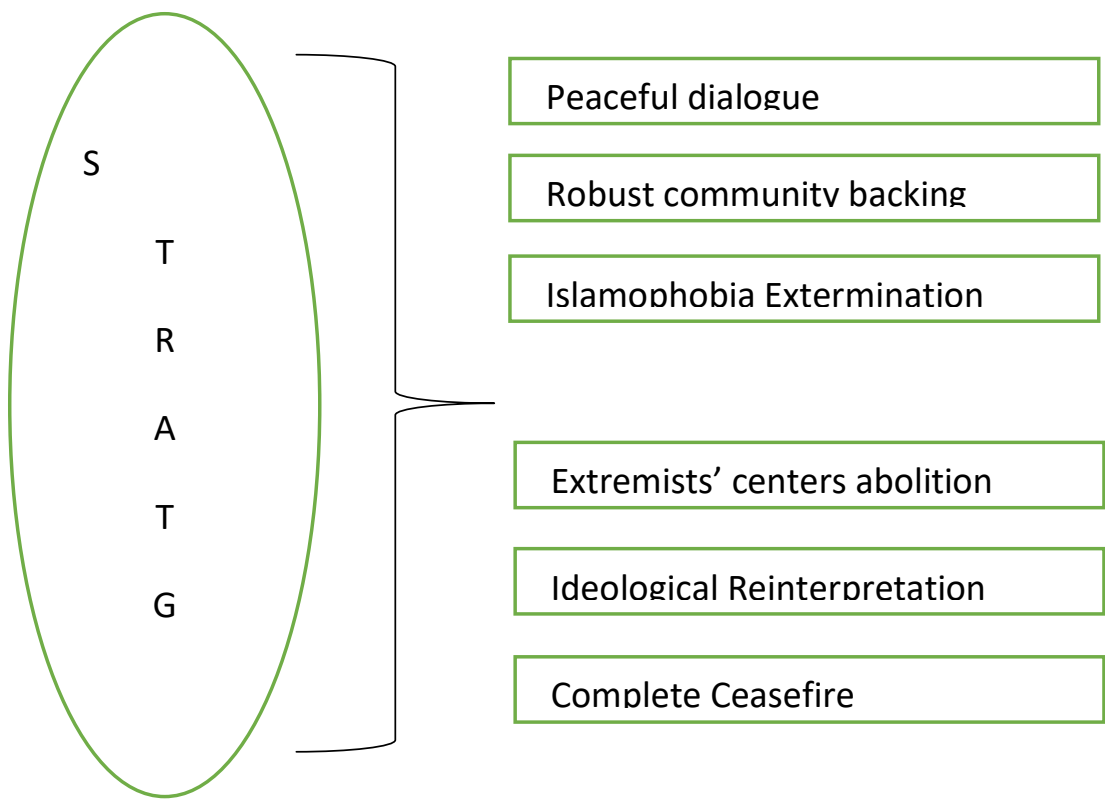

Figure 2: The emerging theme of Strategies

Source: Authors' Own Work 
The figure displays that the strategies to combat violent extremism are peaceful dialogue, strong community support, Islamophobia eradication, extremists' centre's abolition, ideological reinterpretation, and complete ceasefire.

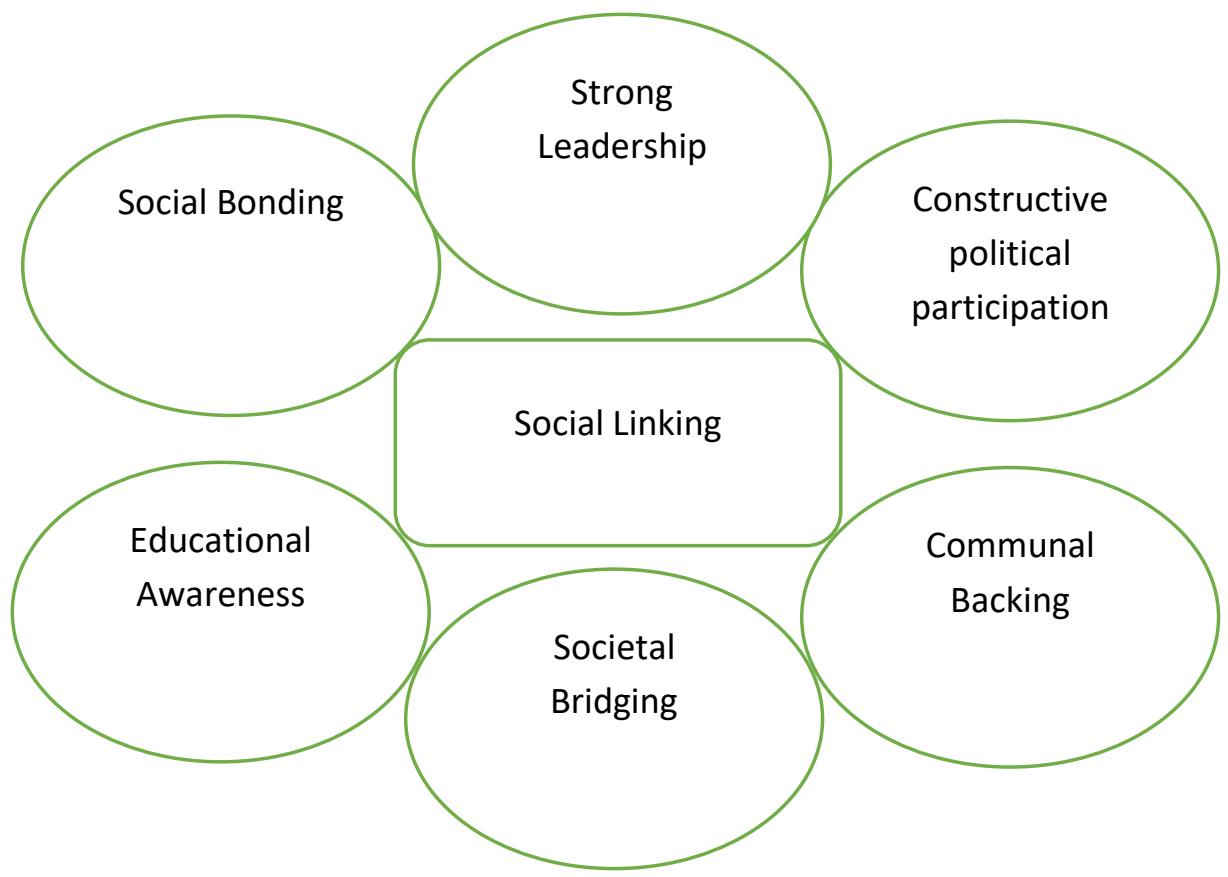

Figure 3: The emerging theme of societal linking

Source: Authors' Work

The figure exhibits that social linking needs social bonding, social bridging, community support, educational awareness, positive political involvement, and strong leadership.

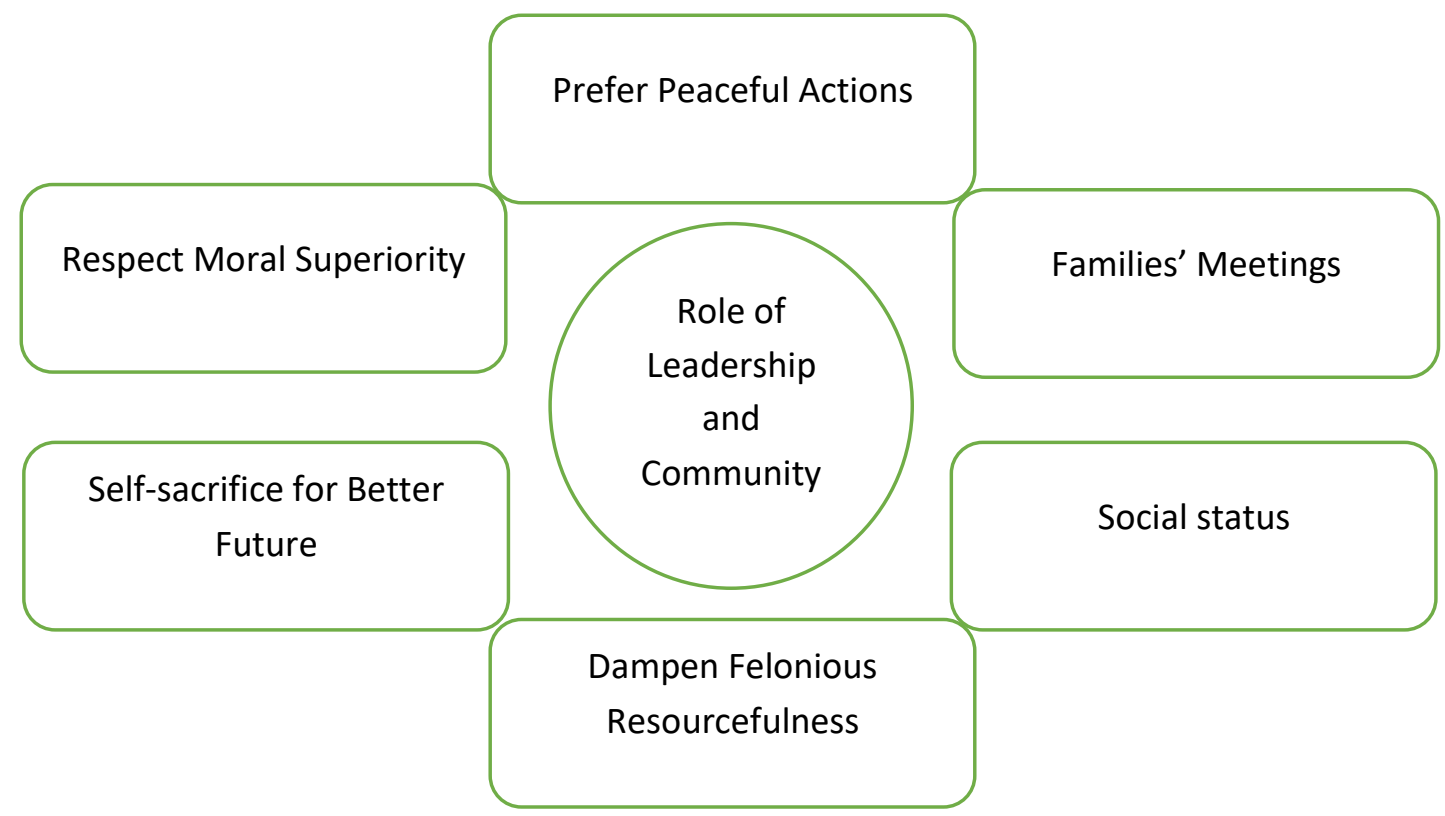

Figure 4: The emerging theme of Community membership \& Community role

Source: Authors' Work

The figure shows that the positive role of leaders and community members requires to prefer positive actions, respect moral superiority, family meetings, social status, self-sacrifice for a better future and discourage criminal opportunism.

After the theme map, the themes are defined and renamed. In the end, the interpretation was correct.

\section{KEY FINDINGS}

The major findings are: 
It was found that the basic reasons for ferocious radicalism are extreme adversity in the area and no proper educational programs for the eradication of illiteracy and ignorance from the youth of the locality. Spirit of Jihad was inculcated in the mind of the youth with so-called ideology and they were recruited regularly and properly by the extremist groups for the fulfillment of their nefarious designs. Injustice is rampant in the area. All the fiscal authority are in the hands of Khans. They were treating the poor with brutality and injustice. An inborn hatred is existing in the poor people against the landlords of the area. It was also found that global monetary avarice to snatch everything of another country was another cause of the violent extremism. It was also produced that nefarious designs of the West have devastated the conditions in Swat because these countries have their designs in the area. It was also found that the strategies to combat violent extremism are peaceful dialogue, strong community support, Islamophobia eradication, extremists' centre's abolition, ideological reinterpretation, and complete ceasefire. It was also found that social linking needs social bonding, social bridging, community support, educational awareness, positive political involvement, and strong leadership. It was also noted from the views of the interviewees' positive role of leaders and community members requires to prefer positive actions, respect moral superiority, family meetings, social status, self-sacrifice for a better future and discourage criminal opportunism. Large buildings are like foundations; strategies on VE; friendship; and community members and community status of statistical analysis are supported by qualification criteria. Similarly, the main themes that emerge from the qualifications are political extremism, authoritarianism, dictatorship, culture, racism, authoritarianism, and hatred of humanity, general opinion, racism, Martyrdom traits, gender stereotypes, intolerance and misunderstanding, Psycho and Terrorism Practices, Anxiety, Cold Sores, Infertility, Disagreement, Social Discrimination, Lack of Hope, Common Core About anti-Semitism, Islamic extremism, The causes of terrorism, Western extremism, anti-Americanism and ideological extremism.

\section{DISCUSSION}

The current research paper delivers a wealth of information in the context of Pakistan on terrorism and extremist violence and not only identifies the root causes of violence, addressing the strategy of fighting VE but also identifying the bridge community and institutions about the problem and then highlight the importance of community members and the community in building public capacity to face this risk. The study further enhances the literature on extremism by writing about support for the relationship between community members and the role of society and CR on violence. It has been found that $\mathrm{CR}$ in VE inhibition signifies a change of pace from a complex conflict, in which people suffer for a critical period, to a way in which union members represent change. It has also been found that building CR works best as it becomes a social system that can gain community trust and allow them to become citizens of the city. It has also been shown that part of communal associates in constructing communal pliability to integrate ferocious radicalism is in line with the study of Hong, Bonczak, Gupta, \& Kontokosta, (2021) and Svennevig, Jerome, and Elwick, (2021) who struggle to prevent and respond Terrorism through Justice is not only the responsibility of the state. The finding is backing the research of Wahab, (2021); Hong, Bonczak, Gupta, and Kontokosta, (2021). It was decided that the origin of VE was the poverty that supported it by research (Pervez, 2020; Subedi, \& Jenkins, 2016) which suggests that lack of funds contributes to the large VE group and economic inequality. Each person's origins, complaints, visions, and hopes can be explored in the wrong way to be able to make a meaningful intervention, tailored to the nature of the community. Senior members of the group have been found to have played a key role in eliminating intimidation and fetching harmony in the country. The finding is buttressed by the research work of (Muzamil, Tschakert, Boruff, \& Shahbaz, 2021). It was determined that communal power and pliability are constructed by including youth and other communal adherents in constructive undertakings- communal work, engagement, and sporting events to alleviate disasters. Bilal, (2021) study backed this finding.

It was concluded that community strength and resilience can be built by involving young people and other community members in positive activities such as social work, employment, and sports activities to increase disaster. This study is supported by research (Bilal, 2021). It has been found that adversity, financial instability, domestic violence, and radicalism may be controlled through increasing social empowerment and this work is supported by the project ( Hussain, Mushtaq, \& Hussain, 2021; Piazza, 2011).

\section{CONCLUSION}

The findings show that the basic reasons for zealotry are adversity, ignorance, voracity, injustice, gripes, ideologies, dogmatic extremism, and societal segregation, egalitarianism, self-defeat, and ritual murder. Many community members and community members are advocating for peaceful dialogue, a ceasefire, the elimination of Islamophobia, the elimination of extremist training centres, the completion of militant networks, and the integration of on community, ideological redemption, and strengthening community support, great strategies for CVE to strengthen community resilience. After this, it was found that many community members and community members show morality, political empowerment, family support, good political participation, community support, organizational impact, public awareness 'in terms of education, strong community members, situation studies, social, and social Reforms are a regular part of social interactions between institutions and communities to strengthen the strengths of communities that do not a high position in society and their involvement in design actions to prevent this terrorism and save humanity from the continuation of the catastrophe. Furthermore, it was concluded that members of the community and the community want to prevent acts of violence, to show commitment to a group ideology, respect for moral values, the promotion of peaceful 
activities, the prevention of criminal abuse, family gatherings, use of iron-on violence, commit suicide for a better future, deal with injustice and grievances, socialize and strengthen community resilience to this danger. There has been a strong correlation between the major community adherents and the strength of the public's resistance to extremism

From the analysis of valid data, it was confirmed that the respondents gave the same answer and supported the results of the census with the addition of additional political force, Dividing colonialism, dictatorship, traditional, ethnic, governmental possession and resistance to humanity, ideological significance, extremism, martyrdom attitudes, gender stereotypes, intolerance and ambiguity, terrorist behavior, sadness, unhappiness, mortality, bigotry, social isolation, hopelessness, common beliefs about anti-Semitism, radical Islam, rational reasons for terrorism, violent extremism in Western Europe, intense hatred of Americans and extremism

\section{Way Ahead}

Discrimination studies and community members' data show that they are expert about basic reasons of brutality, strategic approaches, public relations with organizations, and the constructive character of the community to build communal pliability in young individuals about violence, who prepared to deal with this problem and try to contribute to building their youth capacity but many problems force them to avoid the opportunity career. Studies show a strong need for;

Members of the organization can focus on the economic sustainability of the country to reduce poverty to save people from falling into acts of terrorism.

Members of the Educational Association can focus on providing children with quality education to encourage them from all kinds of dangers and train them on the right path to keep them from becoming rebels in the hands of terrorists.

No poverty and zero Hunger sustainable development goals may be strengthened for the sake of humanity to prohibit the entries of poor people into the wrong organizations.

These Strategies may be adopted i.e. Disaster Preparedness, the greatest tools are the communities themselves in terms of violence, social cohesion, social unity and social interrelation best practices, local encouragement, what makes society so tolerant of extremism? How can we build a community? full participation in the group of people to provide a VE encountering method and solutions, Social interaction, creating programs and social/economic conditions that promote strong relationships, reduce inequalities and inequalities, and improve public relations, training and funding can be provided to community members to create their own experiences that will lead to benefits.

Gaining communal backing to combat vehement brutality, raising mindfulness to remain cautious of surroundings, a great way to thwart terrorist plots. And the philosophy of non-violence can be accepted and taught in people's minds and children at schools and youth at college and University levels.

\section{LIMITATIONS OF THE STUDY}

The researchers conducted this study in Tehsil Khwazakhela district Swat. The sample size was only 08 participants which were conveniently chosen for the study. Due to time constraints and financial crunch, the other areas like Tehsil Matta, Mingora, Shamozai, Kabal, Bahrain, Madyan, Kalam, Malam Jaba, and so many terror-stricken areas were not covered. This study was qualitative but quantitative and mixed methods approaches may be adopted to further investigate the phenomenon of violent extremism in the district Swat. The researchers have made in-depth interviews with political figures and common members of the community, for future research it is suggested to explore the phenomenon of violent extremism with educationists, trade unions, hotel owners, and IDPs (Internally Displaced Persons), and particularly women who suffered a lot.

\section{CO-AUTHOR CONTRIBUTION}

The Co-author contributed well to the investigation of the problem along with the Principal author. He visited district Swat with the Principal author and conducted interviews. The interview protocol has been developed by the Co-author under the guidance of the principal author. It was teamwork. Therefore from the refinement of the topic, formulation of the objection, research questions till references, the co-author collaborated with the principal author. The Co-author wrote the literature review portion of the paper.

\section{REFERENCES}

1. Ahmed, Z. S., \& Zahoor, M. (2020). Impacts of the 'War on Terror on the (De-) Humanization of Christians in Pakistan: A Critical Discourse Analysis of Media Reporting. Islam and Christian-Muslim Relations, 31(1), 85103. https://doi.org/10.1080/09596410.2020.1713569

2. Akram, M., Nasar, A., \& Rehman, A. (2021). Misuse of charitable giving to finance violent extremism; A futuristic actions study amidst COVID-19 pandemic. Social Sciences \& Humanities Open, 4(1), 100-140. https://doi.org/10.1016/j.ssaho.2021.100140

3. Alam, J. (2021). Religious identity and politics: Exploring the causes of the political persecution of religious minorities in Kohat District, Pakistan. Asian Journal of Comparative Politics, https://doi.org/10.1177/2 057891121997577 
4. Bhattacharya, S. (2020). Violence on women an "Acceptable" Assertion in Pakistan. World Affair 24(2), 142158.

5. Bilal, M. (2021). The Politics of Popular Islam: An Ethnographic Exploration of Islamic Revivalism in Pakistan. Politics and Religion Journal, 15(1), 193-219.

6. Burt, C. H., Simons, R. L., \& Gibbons, F. X. (2012). Racial discrimination, ethnic-racial socialization, and crime: A micro-sociological model of risk and resilience. American sociological review, 77(4), 648-677. https://doi.org/10.1177/0003122412448648

7. Chandra, A., Williams, M., Plough, A., Stayton, A., Wells, K. B., Horta, M., \& Tang, J. (2013). Getting actionable about community resilience: The Los Angeles county community disaster resilience project. American journal of public health, 103(7), 1181-1189. https://doi.org/10.2105/AJPH.2013.301270

8. Clarke, V., \& Braun, V. (2014). Thematic analysis. In Encyclopedia of critical psychology (pp. 1947-1952). Springer New York. https://doi.org/10.1007/978-1-4614-5583-7_311

9. Creswell, J. W., \& Poth, C. N. (2016). Qualitative inquiry and research design: Choosing among five approaches. Sage publications.

10. Davies, G., Doering, S., \& Neudecker, C. (2021). The Role of Psychological Assessment in Countering Violent Extremism. NATO Science for Peace and Security Series-E: Human and Societal Dynamics, 152, 297-323. https://doi.org/10.3233/NHSDP210018

11. Fair, C. C., Littman, R., Malhotra, N., \& Shapiro, J. N. (2018). Relative poverty, perceived violence, and support for militant politics: Evidence from Pakistan. Political Science Research and Methods, 6(1), 57-81. https://doi.org/10.1017/psrm.2016.6

12. Hearn, J. H., Finlay, K. A., \& Sheffield, D. (2021). Trying to bring attention to your body when you're not sure where it is: An interpretative phenomenological analysis of drivers and barriers to mindfulness for people with spinal cord injury. British Journal of Health Psychology, 26(1), 161-178. https://doi.org/10.1111/bjhp.12462

13. Hirschi, T. (1969). Key idea: Hirschi's social bond/social control theory. Key Ideas in Criminology and Criminal Justice,(1969), 55-69.

14. Hodge, D. R., Zidan, T., \& Husain, A. (2015). Depression among Muslims in the United States: Examining the role of discrimination and spirituality as risk and protective factors. Social work, 61(1), 45-52. https://doi.org/10.1093/sw/swv055

15. Hong, B., Bonczak, B. J., Gupta, A., \& Kontokosta, C. E. (2021). Measuring inequality in community resilience to natural disasters using large-scale mobility data. Nature Communications, 12(1), 1-9. https://doi.org/10. 1038/s41467-021-22160-w

16. Hussain, I., Mushtaq, S., \& Hussain, G. (2021). Determinants of Religious Intolerance In The Youth of Pakistan. PalArch's Journal of Archaeology of Egypt/Egyptology, 18(4), 2878-2882.

17. Kapur, S. (2021). Bridging the gap between theory and praxis: An exploration of international society's responsibility towards instability in Pakistan, 1947-2020 (Doctoral dissertation, Lancaster University).

18. Kundnani, A., \& Hayes, B. (2018). The Globalisation of Countering Violent Extremism Policies. Undermining Human Rights, Instrumentalising Civil Society. Amsterdam: Transnational Institute.

19. Ma, Z., Guo, S., Deng, X., \& Xu, D. (2021). Community resilience and resident's disaster preparedness: evidence from China's earthquake-stricken areas. Natural Hazards, 1-25. Natural Hazards https://doi.org/10.1007/s11069-021-04695-9

20. Majeed, G. (2021). A Historical Account of Sectarianism in Pakistan and Persecution of Shia Hazara Community of Quetta in Balochistan. Pakistan Social Sciences Review, 5(1), 380-392. https://doi.org/10.35484/pssr.2021(5-I)29

21. Malik, Z. U. A., He, Z., \& Rafay, M. (2019). War on Terrorism in Pakistan: Challenges and Strategic Steps. Vestnik RUDN. International Relations, 19(4), 625-631. https://doi.org/10.22363/2313-0660-2019-19-4625-631

22. Mehfooz, M. (2021). Religious Freedom in Pakistan: A Case Study of Religious Minorities. Religions, 12(1), 51. https://doi.org/10.3390/rel12010051

23. Milena, Z. R., Dainora, G., \& Alin, S. (2008). Qualitative research methods: A comparison between focusgroup and in-depth interview. Annals of the University of Oradea, Economic Science Series, 17(4), 1279-1283.

24. Muzamil, M. R., Tschakert, P., Boruff, B., \& Shahbaz, B. (2021). An extreme climatic event and systemic vulnerabilities in the face of conflict: insights from the Taliban insurgency in Swat, Pakistan. Regional Environmental Change, 21(1), 1-13. https://doi.org/10.1007/s10113-020-01738-y

25. Norris, F. H., \& Alegría, M. (2008). Promoting disaster recovery in ethnic-minority individuals and communities. In Ethnocultural perspectives on disaster and trauma (pp. 15-35). Springer, New York. https://doi.org/10.1007/978-0-387-73285-5_2

26. Piazza, J. A. (2011). Poverty, minority economic discrimination, and domestic terrorism. Journal of Peace Research, 48(3), 339-353. https://doi.org/10.1177/0022343310397404

27. Onwudiwe, I. D., \& Mendie, E. (2021). 15 The impact of terrorism in South Asia. Terrorism, Security and Development in South Asia: National, Regional and Global Implications. https://doi.org/10.432 4/9780429342523-19 
28. Pervez, M. S. (Ed.). (2020). Radicalization in Pakistan: A Critical Perspective (Vol. 40). Routledge. https://doi.org/10.4324/9781003107897

29. Ramakrishna, K. (2021). Book review: Shanthie Mariet D’Souza (Ed.), Countering Insurgencies and Violent Extremism in South and Southeast Asia. 133-136. https://doi.org/10.1177/2347797021992172

30. Rehman, Z. U., Abbas, S., Khan, M. A., Mustafa, G., Fayyaz, H., Hanif, M., \& Saeed, M. A. (2021). Understanding the Language of ISIS: An Empirical Approach to Detect Radical Content on Twitter Using Machine Learning. CMC-COMPUTERS MATERIALS \& CONTINUA, 66(2), 1075-1090. https://doi.org/10.32604/cmc.2020.012770

31. Richards, I. (2020). 'Sustainable Development', Counter-terrorism and the Prevention of Violent Extremism: Right-wing Nationalism and Neo-jihadism in Context. The Emerald Handbook of Crime, Justice and Sustainable Development. Emerald Publishing Limited. https://doi.org/10.1108/978-1-78769-355-520201022

32. Romaniuk, P. (2015). Does CVE work? Lessons learned from the global effort to counter violent extremism. Global Center on Cooperative Security. Retrieved October 10, 2016.

33. Sampson, R. J., Raudenbush, S. W., \& Earls, F. (1997). Neighbourhoods and violent crime: A multilevel study of collective efficacy. Science, 277(5328), 918-924. https://doi.org/10.1126/science.277.5328.918

34. Schanzer, D. H., Kurzman, C., Toliver, J., \& Miller, E. (2016). The challenge and promise of using community policing strategies to prevent violent extremism: A call for community partnerships with law enforcement to enhance public safety. Durham: Triangle Center on Terrorism and Homeland Security.

35. Steeves, H. P. (1994). Phenomenology and the possibility of narrative. Clio, 24(1), 21-37.

36. Subedi, D. B., \& Jenkins, B. (2016). Preventing and Countering Violent Extremism: Engaging Peacebuilding and Development Actors. Counter Terrorist Trends and Analyses, 8(10), 13-19.

37. Svennevig, H., Jerome, L., \& Elwick, A. (2021). Countering violent extremism in education: a human rights analysis. Human Rights Education Review, 4(1), 91-110. https://doi.org/10.7577/hrer.3980

38. Tavakol, S., Dennick, R., \& Tavakol, M. (2012). Medical students' understanding of empathy: a phenomenological study. Medical education, 46(3), 306-316. https://doi.org/10.1111/j.1365-2923.2011.04152.x

39. Ting, X., Yong, B., Yin, L., \& Mi, T. (2016). Patient perception and the barriers to practicing patient-centered communication: A survey and in-depth interview of Chinese patients and physicians. Patient Education and Counseling, 99(3), 364-369. https://doi.org/10.1016/j.pec.2015.07.019

40. Victoroff, J., Adelman, J. R., \& Matthews, M. (2012). Psychological factors associated with support for suicide bombing in the Muslim diaspora. Political Psychology, 33(6), 791-809. https://doi.org/10.1111/j.14679221.2012.00913.x

41. Wahab, S. (2021). Causes \& Consequences of Terrorism in Khyber Pakhtunkhwa, Pakistan. International Journal of Research 8(2), 234-245.

42. Weine, S., Cohen, J., \& Brannegan, D. (2015). Moving beyond motive-based categories of targeted violence (No. ANL/GSS-15/6). Argonne National Lab. (ANL), Argonne, IL (United States). https://doi.org/10.2172/1224067 